\title{
Study of the Emotional Maturity Level in Students of Saveetha Dental College- A Questionnaire Based Study
}

\author{
Nivetha $^{1}{ }^{*}$, Dr. Karpagam Krishnamoorthy ${ }^{2}$
}

\section{ABSTRACT}

Aim: To study the emotional maturity level in students of Saveetha dental college. Objective: To estimate the emotional maturity and its impact on students with to relation to certain factors. Background: To conduct a survey on the emotional maturity level on students by preparing questionnaire with relation to certain factors. In present circumstances, youth as well as children are facing difficulties in life. These circumstances are giving rise to many psychosomatic problems such as anxiety, tension and emotional upsets in day to day life. Emotional maturity is not only the effective determinant of personality pattern but helps to control the growth of adolescent's development. Reason : I am interested to find out the emotional maturity level and to frame scale, based on it the individuals can be given awareness can be counseled for a balanced and sustained maturity.

Keywords: Emotional Maturity, First Year Undergraduates, Female Students.

Emotion may be defined as the stirred up condition of organism involving internal and external changes in body. Emotional maturity is a process which the personal is continuously striving for greater sense of emotional health both intra-psychically and intra- personally [6]. Now a days, Emotional pressure is increasing day to day adolescent stage [4] .Emotions are basic primeval forces by nature to enable the organism to cope up with circumstances which demand the utmost effort for survival. The emotions are the way of acting, as a way of getting along the world [3]. Emotions have strong link with urges, needs and interests. A healthy emotional development cultivates in emotional maturity [5]. Emotionally matured persons can make better adjustment with him as well as with others [2]. According to the Chamberlain (1960), An emotionally matured persons is one whose emotional life is well under control. A mature person's views life experiences as a learning experiences.When they are positive, he enjoys and revels in life. When they are negative, he accepts personal responsibility and his confident and can learn them to

\footnotetext{
${ }^{1}$ First year BDS, Department of Anatomy, Saveetha Dental College and Hospitals, Chennai, India.

${ }^{2}$ Lecturer, Department of Anatomy, Saveetha Dental College and Hospitals, Chennai, India.

*Responding Author

(c) 2016 I Nivetha, K Krishnamoorthy; licensee IJIP. This is an Open Access Research distributed under the terms of the Creative Commons Attribution License (http://creativecommons.org/licenses/by/2.0), which permits unrestricted use, distribution, and reproduction in any Medium, provided the original work is properly cited.
} 


\section{Study of the Emotional Maturity Level in Students of Saveetha Dental College - A Questionnaire Based Study}

improve his life. When things do not go well, matured person looks for an opportunity. When things do not go as anticipated ,the immature persons stamps his feet ,holds his breath and bemoans his fate[1].

\section{MATERIALS AND METHODS:}

A questionnaire containing of 17 questions which measures the emotional maturity level of the individuals was prepared .A questionnaire was distributed to randomly chosen 52 girls who were studying in the saveetha dental college. This questionnaire consists of all positively worded questions. This questionnaire is "YES OR NO" type question. The score between 0-9 were considered as low emotional maturity level. The score between 10-17 were considered as a high emotional maturity level. The participants were asked to seated comfortably and the questionnaire was given to them. The instruction were given and answering these question accurately requires honest reflection on how you really think, feel, and act in general and may be taking test on more than one occasion. The response was scored and the results were tabulated.

\section{RESULTS}

\section{Score Of Each Female Students}

\begin{tabular}{|l|l|}
\hline S.NO & SCORE \\
\hline 1 & 15 \\
\hline 2 & 10 \\
\hline 3 & 17 \\
\hline 4 & 12 \\
\hline 5 & 7 \\
\hline 6 & 6 \\
\hline 7 & 11 \\
\hline 8 & 14 \\
\hline 9 & 17 \\
\hline 10 & 15 \\
\hline 11 & 8 \\
\hline 12 & 6 \\
\hline 13 & 9 \\
\hline 14 & 15 \\
\hline 15 & 15 \\
\hline 16 & 14 \\
\hline 17 & 14 \\
\hline 18 & 15 \\
\hline 19 & 16 \\
\hline
\end{tabular}

(c) The International Journal of Indian Psychology, ISSN 2348-5396 (e)| ISSN: 2349-3429 (p) | 195 
Study of the Emotional Maturity Level in Students of Saveetha Dental College

- A Questionnaire Based Study

\begin{tabular}{|c|c|}
\hline 20 & 9 \\
\hline 21 & 16 \\
\hline 22 & 16 \\
\hline 23 & 16 \\
\hline 24 & 10 \\
\hline 25 & 17 \\
\hline 26 & 14 \\
\hline 27 & 14 \\
\hline 28 & 17 \\
\hline 29 & 17 \\
\hline 30 & 11 \\
\hline 31 & 14 \\
\hline 32 & 14 \\
\hline 33 & 13 \\
\hline 34 & 13 \\
\hline 35 & 17 \\
\hline 36 & 13 \\
\hline 37 & 13 \\
\hline 38 & 9 \\
\hline 39 & 8 \\
\hline 40 & 14 \\
\hline 41 & 14 \\
\hline 42 & 10 \\
\hline 43 & 8 \\
\hline 44 & 10 \\
\hline 45 & 12 \\
\hline 46 & 14 \\
\hline 47 & 16 \\
\hline 48 & 7 \\
\hline 49 & 6 \\
\hline 50 & 11 \\
\hline 51 & 9 \\
\hline 52 & 10 \\
\hline
\end{tabular}

Average: 12.95

Highest Score: 17

Lowest Score: 6

(c) The International Journal of Indian Psychology, ISSN 2348-5396 (e)| ISSN: 2349-3429 (p) | 196 
Study of the Emotional Maturity Level in Students of Saveetha Dental College

- A Questionnaire Based Study

Score Of High And Low Maturity Level Students

\begin{tabular}{|l|l|}
\hline $\begin{array}{l}\text { SCORE OF HIGH } \\
\text { MATURITY LEVEL } \\
\text { STUDENTS }\end{array}$ & $\begin{array}{l}\text { SCORE OF LOW } \\
\text { MATURITY LEVEL } \\
\text { STUDENTS }\end{array}$ \\
\hline 15 & 7 \\
\hline 10 & 6 \\
\hline 16 & 8 \\
\hline 12 & 6 \\
\hline 17 & 9 \\
\hline 11 & 9 \\
\hline 14 & 9 \\
\hline 17 & 8 \\
\hline 17 & 8 \\
\hline 15 & 7 \\
\hline 15 & 6 \\
\hline 14 & 9 \\
\hline 14 & \\
\hline 15 & \\
\hline 16 & \\
\hline 16 & \\
\hline 10 & \\
\hline 17 & \\
\hline 14 & \\
\hline 14 & \\
\hline 17 & \\
\hline 17 & \\
\hline 11 & \\
\hline 14 & \\
\hline 14 & \\
\hline 13 & \\
\hline 17 & \\
\hline 13 & \\
\hline 14 & \\
\hline 10 & \\
\hline 10 & \\
\hline 12 & \\
\hline 16 & \\
\hline 11 & \\
\hline 10 & \\
\hline & \\
\hline & \\
\hline & \\
\hline
\end{tabular}

(c) The International Journal of Indian Psychology, ISSN 2348-5396 (e)| ISSN: 2349-3429 (p) | 197 
Study of the Emotional Maturity Level in Students of Saveetha Dental College

- A Questionnaire Based Study

Overall Score

\begin{tabular}{|l|l|l|l|}
\hline & OVERALL & $\begin{array}{l}\text { HIGH MATURITY } \\
\text { LEVEL }\end{array}$ & $\begin{array}{l}\text { LOW MATURITY } \\
\text { LEVEL }\end{array}$ \\
\hline AVERAGE & 12.96 & 13.95 & 7.83 \\
\hline NO.OF. SUBJECTS & 52 & 40 & 12 \\
\hline HIGHEST SCORE & 17 & 17 & 9 \\
\hline LOWEST SCORE & 6 & 10 & 6 \\
\hline
\end{tabular}
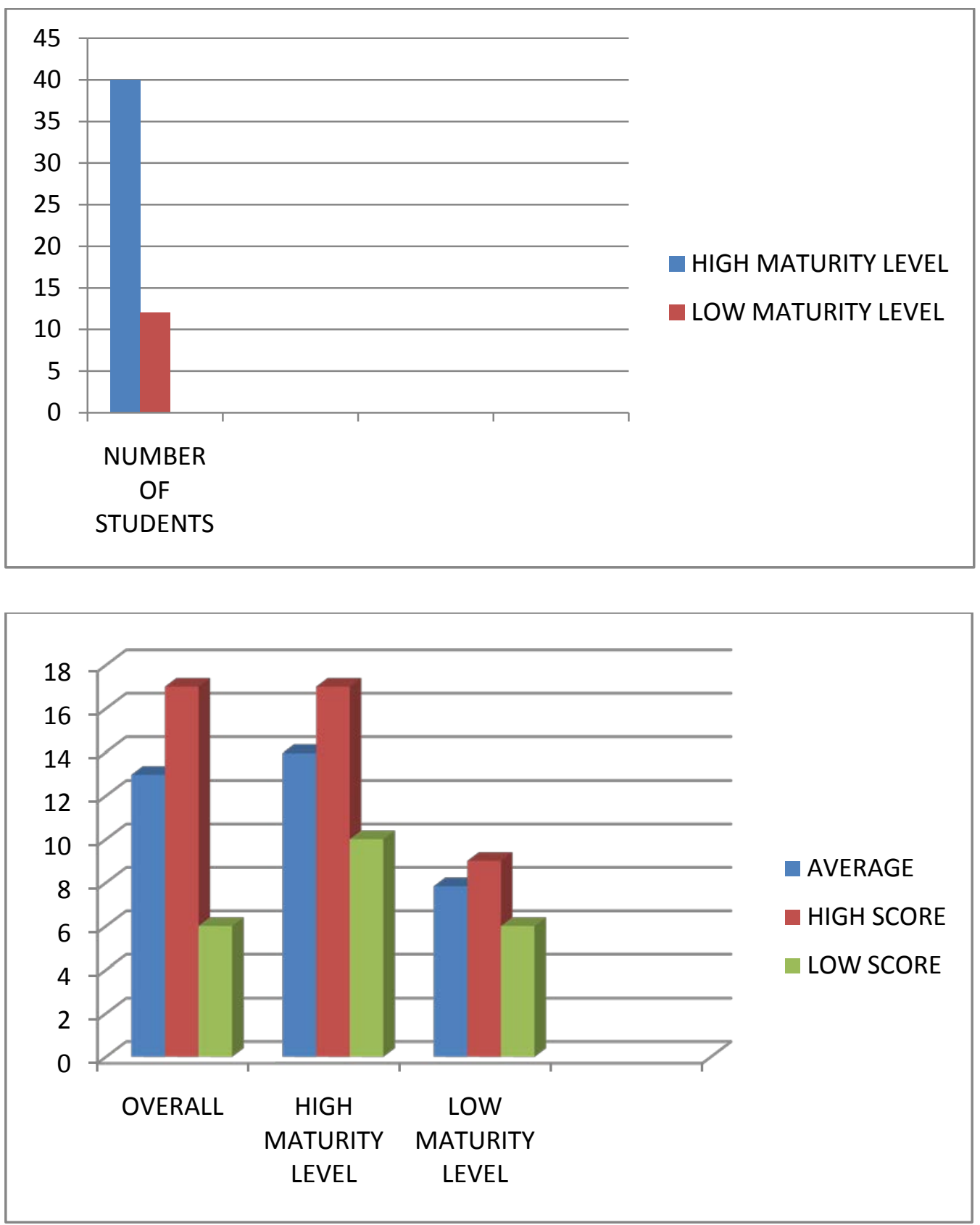

(c) The International Journal of Indian Psychology, ISSN 2348-5396 (e)| ISSN: 2349-3429 (p) | 198 


\section{Study of the Emotional Maturity Level in Students of Saveetha Dental College - A Questionnaire Based Study}

\section{DISCUSSION}

In the results, individuals character are divided into two categories based upon their emotional scores as high maturity level and low maturity level. The average value of overall dimensions is found to be 12.96 which falls under the high maturity level. The average value of students who falls under the high maturity level is 13.95 whereas the average value of students who falls under low maturity level is 7.83. From the chart, it is clear that the number of high maturity level students is 40 which is higher than the number of low maturity level students. From the results, it is clear that the highest and lowest score of students in high maturity level is 17 and 10 . Similarly, the highest and lowest score of students in low maturity level is 9 and 6.

\section{CONCLUSIONS}

The present study may helps the parents and teachers to have knowledge emotional development of their children and students and help them to build a well balanced personality. Students in high maturity level leads to happy, rewarding and satisfying life. Students in low maturity level leads to getting upset easily, having low frustration level, extremely jealousy, unwillingness to forgive and unpredictable fluctuation of moods. So, students in low maturity level can be given psychological counseling or some activities that can help to increase the emotional maturity level are Be honest with our self, do things for others and expand our social circle. Individuals differ in their emotional maturity level.

\section{REFERENCES}

1) Aleen S(2005) -Emotional stability among college youth. J. Indian Acad. Appl.Psychol.,31:99-109

2) Dalwinder Singh, Simerjeet Kaur and Gaurav Dureja-Emotional maturity differentials among university students.

1 Department of Physical Education, Panjab University, Chandigarh INDIA.

2 Department of Physical Education, DAV Model School,Sec-15, Chandigarh INDIA

3 Department of Physical Education(TE\&L) , Post Graduate Government College , Sector-11, Chandigarh INDIA.

3) Dosanjh (1960) , Imagination and Maturity as Factor Indicative success in Teaching .Doctoral Thesis, Panjab University.

4) Jadab Dutta ,Dr. Pranab Chetia - A Comparative study on emotional maturity of secondary school students in Sonitpur Districts of ASSAM.

5) Seoul, L.J.,(1951) - Emotional maturity ,The Development and Dynamics of Personality, LONDON.

6) Smitson , W.S.(1974) ,The meaning of emotional maturity,MH,58,9-11

How to cite this article: Nivetha, K Krishnamoorthy (2016), Study of the Emotional Maturity Level in Students of Saveetha Dental College- A Questionnaire Based Study, International Journal of Indian Psychology, Volume 3, Issue 3, No. 11, DIP: 18.01.210/20160303, ISBN: 978$1-365-21307-6$

(C) The International Journal of Indian Psychology, ISSN 2348-5396 (e)| ISSN: 2349-3429 (p) | 199 